\title{
Effects of Cadmium (Cd) on Dry Matter and on Cd Concentration in Leaves and Roots of Purple Coneflower (Echinacea purpurea L.)
}

\author{
Alexandra SALTA ${ }^{1}$, Anastasia AKOUMIANAKI-IOANNIDOU ${ }^{1 *}$, Pantelis E. BAROUCHAS ${ }^{3}$, Nicholas K. \\ MOUSTAKAS $^{2}$ \\ ${ }^{1}$ Laboratory of Floriculture and Landscape Architecture, Department of Crop Science, School of \\ Agriculture, Engineering and Environmental Sciences, Agricultural University of Athens, Iera Odos 75, \\ 118 55, Athens \\ ${ }^{2}$ Laboratory of Soil Science and Agricultural Chemistry, Department of Crop Science, School of \\ Agriculture, Engineering and Environmental Sciences, Agricultural University of Athens, Iera Odos 75, \\ 11855 , Athens \\ ${ }^{3}$ Technological Educational Institute of Western Greece \\ *corresponding author, e-mail: akouman@aua.gr
}

BulletinUASVM Horticulture 76(1) / 2019

Print ISSN 1843-5254, Electronic ISSN 1843-5394

DOI:10.15835/buasvmcn-hort: 2018.0028

\begin{abstract}
The aim of this research was to examine the effect of Cd on leaves dry matter (LDM), root dry matter (RDM) and on Cd concentration in leaves (Cd-leaves) and roots (Cd-roots) of purple coneflower (E. purpurea) grown in an acid and in a neutral substrate. A completely randomized block design with four treatments ( 0 -control, 1, 2, and $5 \mathrm{mg}$ $\mathrm{Cd} \mathrm{L}^{-1}$ ) and six replications for each treatment and each substrate (acid, neutral) was conducted in pot experiments. $\mathrm{Cd}$ concentration in leaves grown in acid substrate as well as in roots of plants grown in neutral substrate increased at Cd rates greater than $2 \mathrm{mg} \mathrm{Cd} \mathrm{L}^{-1}$. Cd concentration in roots of the plants grown in neutral substrate raised with increasing doses of $\mathrm{Cd}$. In general $\mathrm{Cd}$ concentration in the roots and leaves of purple coneflower grown either in acid or in neutral substrate was affected by $\mathrm{Cd}$ applications.
\end{abstract}

Keywords: heavy metals, medicinal plant, substrate reaction

\section{Introduction}

Cadmium (Cd) is one of the most deleterious trace heavy metals both for plants and animals. With the development of modern industry and agriculture, $\mathrm{Cd}$ has become one of the most harmful and widespread pollutants in agricultural soils. This element is widespread in the soil-plantenvironment system mainly due to industrial emission, the application of Cd-containing sewage sludge and phosphate fertilizers and municipal waste disposal (Gupta and Gupta, 1998). Cd contamination is a non-reversible accumulation process, with the estimated half-life in soil varying between 15 and 1100 years (Kabata -Pendias and Pendias, 2001), with a high plant-soil mobility easily accumulated in plant tissues, while high accumulation of Cd in plants not only badly affects crop yield and quality, but also gives rise to a threat on human health via food chain. In humans, Cd accumulates mainly in the kidneys with a biological half-life of about 20 years, and leads to pulmonary emphysema and renal tubular damage (Godt et al., 2006). Hence, Cd is one of the metals for which the Food and Agricultural Organization and the World Health Organization (1978) have set limits, with a maximum permitted human intake 
Table 1. Leaves dry matter (LDM), roots dry matter (RDM) and Cd concentration in leaves and roots of purple cone flower plants grown on a neutral substrate treated with $\mathrm{Cd}$

\begin{tabular}{|c|c|c|c|c|}
\hline Cd added (mg L $\left.{ }^{-1}\right)$ & $\begin{array}{l}\text { LDM } \\
\text { (g) }\end{array}$ & $\begin{array}{c}\text { RDM } \\
\text { (g) }\end{array}$ & $\begin{array}{l}\text { Cd in leaves } \\
\left(\mu g \mathrm{~L}^{-1} \mathrm{DW}\right)\end{array}$ & $\begin{array}{l}\text { Cd in roots } \\
\left(\mu \mathrm{g} \mathrm{L}^{-1} \mathrm{DW}\right)\end{array}$ \\
\hline 0 -control & $1.55 \mathrm{a}$ & 8.21 & $1.70 \mathrm{a}$ & $8.67 \mathrm{a}$ \\
\hline 1 & $2.01 \mathrm{~b}$ & 8.49 & $1.67 \mathrm{a}$ & $9.67 \mathrm{ab}$ \\
\hline 2 & $1.69 \mathrm{ab}$ & 9.83 & $3.67 \mathrm{a}$ & $12.33 \mathrm{ab}$ \\
\hline 5 & $1.39 \mathrm{a}$ & 9.02 & $9.00 \mathrm{~b}$ & $14.67 \mathrm{~b}$ \\
\hline $\mathrm{F}$ & 5.76 & & 9.83 & 13.2 \\
\hline
\end{tabular}

Mean values/column followed by the same letter are not significantly different, according to Duncan's multiple range test, at $p \leq 0.05$; Mean values/column without letters indicate no significance by Duncan's test at $\mathrm{P} \leq 0.05$; DW=dry weight;

Table 2. Leaves dry matter (LDM), roots dry matter (RDM) and Cd concentration in leaves and roots of purple cone flower plants grown on an acid substrate treated with $\mathrm{Cd}$

\begin{tabular}{|c|c|c|c|c|}
\hline Cd added (mg L $\left.{ }^{-1}\right)$ & $\begin{array}{c}\text { LDM } \\
\text { (g) }\end{array}$ & $\begin{array}{c}\text { RDM } \\
\text { (g) }\end{array}$ & $\begin{array}{l}\text { Cd in leaves } \\
\left(\mu g \mathrm{~L}^{-1} \mathrm{DW}\right)\end{array}$ & $\begin{array}{l}\text { Cd in roots } \\
\left(\mu \mathrm{g} \mathrm{L}^{-1} \mathrm{DW}\right)\end{array}$ \\
\hline 0 -control & $2.12 \mathrm{a}$ & 1.63 & $5.33 \mathrm{a}$ & $10.00 \mathrm{a}$ \\
\hline 1 & $1.36 \mathrm{~b}$ & 1.58 & $7.33 \mathrm{~b}$ & $14.00 \mathrm{a}$ \\
\hline 2 & $2.02 \mathrm{a}$ & 1.51 & $7.33 \mathrm{~b}$ & $26.67 \mathrm{a}$ \\
\hline 5 & $2.49 \mathrm{a}$ & 1.92 & $8.33 \mathrm{~b}$ & $64.67 \mathrm{~b}$ \\
\hline $\mathrm{F}$ & 7.25 & & 10.2 & 4.5 \\
\hline
\end{tabular}

Mean values/column followed by the same letter are not significantly different, according to Duncan's multiple range test, at $p \leq 0.05$; Mean values/column without letters indicate no significance by Duncan's test at $\mathrm{P} \leq 0.05$; $\mathrm{DW}=\mathrm{dry}$ weight;

of Cd $70 \mu \mathrm{g} \mathrm{d}^{-1}$. The genus Echinacea (Asteraceae) comprises a small number of species that are hardy, herbaceous perennial plants, native to parts of North America. Three of the species, E. angustifolia (DC.) Hell., E. pallida (Nutt.) Nutt. and E. purpurea (L.) Moench. have medicinal use (Barns et al., 2005). Echinacea species have been described as the most important plants traditionally used by the Native Americans for treatment of many diseases, including colds, tonsillitis, toothaches, bowel pain, snake bites, rabies, seizures, wound infections, septic conditions and cancer. Nowadays, Echinacea-containing drugs and products have great popularity in Europe, particularly in Germany. Fluid extracts of Echinacea purpurea are currently used as immune-stimulating agents for the treatment and prevention of various infectious disorders, including colds and infections of the upper and lower respiratory system (Grimm and Muller, 1999). The fresh or dried underground parts (roots, rhizomes) of the three mentioned Echinacea species are used in medicine along with the fresh or dried flowering tops and the fresh pressed juice from E. purpurea (Barns et al., 2005). The aim of this research was to examine the effects of Cd on LDM, RDM and on Cd concentration in leaves and roots of purple coneflower grown in an acid or in a neutral substrate.

\section{Materials and methods}

Pot experiments were conducted under greenhouse conditions at the Agricultural University of Athens in the autumn of 2016 for four months. Pots were arranged in a completely randomized block design in two groups (acid substrate, neutral substrate) with four treatments of Cd (0-control, 1, 2 and $5 \mathrm{mg} \mathrm{Cd} \mathrm{L}^{-1}$ ) and six replications per treatment. In the first group, on acid substrate (24 pots), plantlets were transplanted in peat with $\mathrm{pH}=5.6$ and perlite $1: 1$ $(\mathrm{v} / \mathrm{v})$ and in the second group on neutral substrate ( 24 pots), in peat with $\mathrm{pH}=6.8$ and perlite $1: 1$ $(\mathrm{v} / \mathrm{v})$. Cadmium (Cd) was applied in concentration of $0,1,2$ and $5 \mathrm{mg} \mathrm{L}^{-1}$ to pots containing one plant each. Treatments started in the $3^{\text {rd }}$ week after transplanting, and have been applied 
twice a week for five weeks. Fertilization was performed approximately every two weeks, using a commercial fertilizer (Nutrileaf-60) with $2 \mathrm{mg} \mathrm{N}$, $2 \mathrm{mg} \mathrm{P}_{2} \mathrm{O}_{5}$, and $2 \mathrm{mg} \mathrm{K}_{2} \mathrm{O}$ for each pot (the content of $\mathrm{Cd}$ in the fertilizer was negligible). At the end of the experiment, leaves and roots were harvested and were oven-dried at $50{ }^{\circ} \mathrm{C}$ to constant weight, ground in a stainless steel Wiley mill and passed through a $250 \mu \mathrm{m}$ plastic sieve, $0.5 \mathrm{~g}$ of plant parts smaller than $250 \mu \mathrm{m}$ in diameter from each pot were placed in beakers and ashed at $450{ }^{\circ} \mathrm{C}$. The residue was dissolved in $5 \mathrm{ml}$ of $6 \mathrm{~N} \mathrm{HCl}$. The clear solutions were analyzed by Atomic Absorption Spectrometry (VARIAN A-300). ANOVA's were calculated using STATISTICA ${ }^{\mathrm{TM}}$ Ver. 8.0 (StatSoft 2008). Where a significant difference was found, the Duncan's Multiple Range Test at the 5\% level of probability was used to compare individual treatment means.

\section{Results and discussion}

Visual examinations of Cd-treated plants of purple coneflower did not reveal symptoms of toxicity or of nutrient deficiency over the concentration range of $0-5 \mathrm{mg} \mathrm{Cd} \mathrm{\textrm {L } ^ { - 1 }} \mathrm{Cd}$ concentration in leaves grown in acid substrate as well as in roots of purple coneflower plants grown on neutral substrate increased at $\mathrm{Cd}$ doses higher than $2 \mathrm{mg} \mathrm{Cd} \mathrm{L}^{-1}$ (Tab. 1 and 2). Cd concentration in roots of the plants grown on neutral substrate raised with increasing doses of $\mathrm{Cd}$ (Tab. 1). Significant differences of Cd concentration in leaves between control and the other $\mathrm{Cd}$ treatments were observed in the plants grown on an acid substrate (Tab. 2). Cd concentration in the roots and leaves of purple coneflower plants grown either on an acid or a neutral substrate, raised with increasing Cd applications (Tab. 1 and 2). These results are in accordance with the $\mathrm{Cd}$ concentration observed in leaves of lettuce, radish and cucumber (Moustakas et al., 2001) as well as in edible tissues of endive and rocket (Akoumianakis et. al., 2008).

\section{Conclusions}

Leaves dry matter of purple coneflower grown on acid medium were not affected by $\mathrm{Cd}$ applications but the opposite was observed in roots dry matter grown on a neutral medium. $\mathrm{Cd}$ concentration in leaves and roots increased following $\mathrm{Cd}$ applications either to an acid or a neutral medium.

\section{References}

1. Akoumianakis KA, Passam HC, Barouchas PE, Moustakas NK (2008). Effect of cadmium on yield and cadmium concentration in the edible tissues of endive (Cichorium endivia L.) and rocket (Eruca sativa Mill.) Journal of Food, Agriculture \& Enviroment, 6 (3-4): 206-209.

2. Barns J, Anderson L, Gibbons S, Phillipson D (2005), Echinacea species (Echinacea angustifolia (DC.) Hell., Echinacea pallida (Nutt.) Nutt., Echinacea purpurea (L.) Moench): a review of their chemistry, pharmacology and clinical properties, Journal of Pharmacy and Pharmacology, 57: 929-954.

3. Food and Agricultural Organization and World Health Organization (1978). List of Maximum Levels Recommended for Contaminants by the Joint FAO/WHO, Codex Alimentarius Commission. 3rd series, CAC/FAL 4-1978, FAO/WHO, Rome.

4. Godt J, Scheidig F, Grosse-Siestrup C, Esche V, Brandenburg P, Reich A, Groneberg DA (2006). The toxicity of cadmium and resulting hazards for human health. Journal of Occupational Medicine and Toxicology, 1:22.

5. Grimm W and Muller HH (1999). A Randomized Controlled Trial of the Effect of Fluid Extract of Echinacea Purpurea on the Incidence and Severity of Colds and Respiratory Infections, The American Journal of Medicine, 106: 138143.

6. Gupta UC and Gupta SC (1998). Trace element toxicity relationships to crop production and livestock and human health: Implications for management. Communications in Soil Science and Plant analysis, 29: 1491-1522.

7. Kabata-Pendias A and Pendias H (2001). Trace elements in soils and plants, 3rd ed. CRC Press Inc, Boca Raton, FL.

8. Moustakas NK, Akoumianakis KA, Passam HC (2001). Cadmium accumulation and its effect on yield of lettuce, radish and cucumber. Communications in Soil Science and Plant analysis, 32(11-12): 1793-1802.

9. StatSoft Inc (1998) STATISTICA for Windows. Tulsa, OK; StatSoft Inc. 